\title{
Correction: Cell death upon epigenetic genome methylation: a novel function of methyl-specific deoxyribonucleases
}

\author{
Eri Fukuda ${ }^{1,2}$, Katarzyna H Kaminska ${ }^{4,3}$, Janusz M Bujnicki ${ }^{1,4,3}$ and Ichizo Kobayashi ${ }^{1,2,5^{*}}$
}

\section{Correction}

We have noticed an error in the sixth paragraph of the Discussion of our article [1]. The corrected paragraph should read:

Another type IV nuclease, GmrSD, found in an E. coli strain targets glucosylated hydroxymethyl-C and may have evolved to cut T4 genome [78]. The resistance of hydroxymethyl-C-containing phage to restriction enzymes but its sensitivity to McrBC [79], the resistance of glucosylated hydroxymethyl-C to McrBC but sensitivity to GmrSD [78], and inhibition of GmrSD by T4coded internal protein [78] suggest an evolutionary arms race (evolutionary struggle between competing sets of co-evolving genes that develop adaptations and counteradaptations against each other) between the bacteria and the phage.

\footnotetext{
Author details

${ }^{1}$ Laboratory of Social Genome Sciences, Department of Medical Genome Sciences, University of Tokyo, 4-6-1 Shirokanedai, Minato-ku, Tokyo, 108-8639, Japan. ${ }^{2}$ Graduate Program in Biophysics and Biochemistry, Graduate School of Science, University of Tokyo, 4-6-1 Shirokanedai, Minato-ku, Tokyo, 1088639, Japan. ${ }^{3}$ International Institute of Molecular and Cell Biology, Trodena 4, 02-109 Warsaw, Poland. ${ }^{4}$ Faculty of Biology, Adam Mickiewicz University, Umultowska 89, 61-614 Poznan, Poland. ${ }^{5}$ Institute of Medical Science, University of Tokyo, 4-6-1 Shirokanedai, Minato-ku, Tokyo, 108-8639, Japan.
}

Received: 16 November 2011 Accepted: 23 November 2011 Published: 15 January 2012

\section{Reference}

1. Fukuda E, Kaminska KH, Bujnicki JM, Kobayashi I: Cell death upon epigenetic genome methylation: a novel function of methyl-specific deoxyribonucleases. Genome Biology 2008, 9:R163.

\footnotetext{
* Correspondence: ikobaya@ims.u-tokyo.ac.jp

${ }^{1}$ Laboratory of Social Genome Sciences, Department of Medical Genome Sciences, University of Tokyo, 4-6-1 Shirokanedai, Minato-ku, Tokyo, 108-8639, Japan
}

Full list of author information is available at the end of the article doi:10.1186/gb-2011-12-11-412

Cite this article as: Fukuda et al.: Correction: Cell death upon epigenetic genome methylation: a novel function of methyl-specific deoxyribonucleases. Genome Biology 2011 12:412.
Submit your next manuscript to BioMed Central and take full advantage of:

- Convenient online submission

- Thorough peer review

- No space constraints or color figure charges

- Immediate publication on acceptance

- Inclusion in PubMed, CAS, Scopus and Google Scholar

- Research which is freely available for redistribution

\section{() Biomed Central}

